\title{
Souvenirs and Tourism Promotion in Ghana
}

\author{
Samuel B. Owusu-Mintah \\ Department of Tourism \\ Cape Coast, Polytechnic, P.O.Box AD 50, Cape Coast, Ghana \\ E-mail:omintab2004@yahoo.co.uk
}

\begin{abstract}
This paper examines the types of souvenirs produced and their importance in the promotion of tourism in Ghana. The study also seeks to identify the motives behind the purchase of souvenirs by tourists visiting the country and it further evaluates the operations of the Accra Arts Centre in the sale of authentic souvenirs to tourists. As souvenirs bought by tourists constitute a major aspect of tourism products of every destination, this study, based on a research work conducted in May 2010, involved a sample size of fifty stakeholders in the souvenir trade at the Arts Centre in Accra, Ghana. Structured questionnaires administered to the respondents, were analysed using simple statistical methods such as frequencies and percentages. The paper argues that souvenirs are as important as the places where they are made and concludes that souvenirs bought by tourists visiting Ghana must be so authentic and finished in such a way that they could compare favourably with others from internationally acclaimed tourism destinations around the world.
\end{abstract}

Keywords: souvenirs; artifacts; memento; promotion; authenticity.

\section{Introduction}

Whenever tourists visit places of interest, they would like to carry reminders of their tours back to their places of origin. One way they do this is by buying some items and sending them home as souvenirs. These souvenirs apart from reminding the tourists of their tours, also invite other people, be they friends or relatives, to wish to travel to such places of the souvenirs. Souvenirs are, therefore, a collection of artifacts and experiences that remind tourists of visits they have made to places of interest. Ultimately, souvenirs help to shape the lives, thoughts and perceptions that tourists have about places visited (Salter and Meserve, 1991).

According to the Chambers 21st Century Dictionary (2004), a souvenir is something that is bought, kept or given as a reminder of a place, person, occasion; a memento. Hitchcock (2000), reports that souvenirs are integral to the material culture and identity of a tourist destination. They also become part of the memory of the tourists about places visited and are therefore subject to re-interpretation and reevaluation. Souvenirs are used by tourists to lay claim to a new experience, assert that one has achieved something or have been to somewhere of significance
(Briggs, 1980; Boynton, 1986 and Gordon, 1986). Shenhav-Keller (1993) refers to souvenirs as authentic reminders of tours. The acquisition of a souvenir is not just the collection of objects but of memories and by extension, the experience that provide those memories to people who made the tours.

The various definitions of souvenirs presented above show that souvenirs are indispensable items in travel and tourism. They help in the understanding of the various motives of tourists after exploring the apparent reasons why they decide to visit the places on their itinerary. The souvenir urge reflects the drive for one to expand his experience and understanding of the world as he touches artifacts, reflects on and shows them to others (Gordon, 1986). Although souvenirs can now be purchased on the internet owing to ecommerce (Abendroth, 2011), there is nothing more exciting than a tourist buying a necklace showing a golden cocoa pod from its source. In this way, souvenirs can help others to picture and understand the socio-economic lives of people living at the places visited by tourists. Souvenirs therefore are considered an important aspect of tourism, hence, the need for procedures to produce a variety of them to tell a country's story to visitors.

The main objective of this paper is to examine the 
nature and importance of souvenirs in the promotion of tourism in Ghana. The specific objectives are to identify the types of souvenirs patronized by tourists visiting Ghana, examine the roles of important stakeholders in the souvenir trade at the Accra Arts Centre, delve into problems associated with souvenir production in the country and suggest possible solutions to problems faced by producers of souvenirs so that they can improve their production and promotion as tourism products in the country.

The questions that this study attempts to answer are: What types of souvenirs are produced and usually bought by international tourists visiting Ghana? Who are the major stakeholders in the souvenir trade at the Accra Arts Centre? What are the major problems faced by producers of tangible souvenirs in Ghana? How can problems faced by producers of souvenirs in Ghana be solved? This research work is undertaken to answer these and many other questions that arise from the consideration of souvenirs as important items for tourism promotion.

\section{Discussion of conceptual issues}

\subsection{Authenticity and the Souvenir Trade}

Whenever a tourist acquires a souvenir, he would always like to ensure its authenticity. Authenticity of souvenir is, therefore, of prime concern to the tourist. Appadurai (1986) described authenticity as an issue of expert knowledge and good taste. Because souvenirs will be an item for keep for a long time by tourist, they need to be very authentic to last for a long time. Authentic items may be referred to as genuine, reliable, trustworthy and true to the original.

Authenticity does not relate only to tangible objects, but also to intangible experiences that tourists will enjoy at a destination. According to Lane and Waitt (2007), tourist desires for an authentic experience of place are now well understood within the literature and are generally interpreted in terms of a response to the structures of modernity on daily lives of the people (Franklin and Crang, 2001; Olsen, 2002). Tourists visiting cultural events and activities such as festivals will like to observe the real acts, although certain aspects may not be readily available to the general public. The activities open to the general public will enable tourists make up their minds regarding how authentic the festival is.

\subsection{Classification of souvenirs}

According to Salter and Meserve (1991) and Shenhav-Keller (1993), not all souvenirs can be touched and shown to others, so they put forward a classification of souvenirs into two: that is tangible souvenirs and intangible souvenirs. Tangible souvenirs are products that can be touched. It could also be perceived as a visible sign of personal accomplishment or an authentic reminder of a place visited or an event attended. Tangible souvenirs may include artifacts, photographs, brochures, T-shirts, beads, kente cloth or a smock, which tourists buy on their trip. Souvenirs could also be objects collected from nature such as sand, stones, or shells, rather than commodities purchased at shops (Lane and Waitt, 2007), which are selected because they are unique to the places visited.

On the other hand, an intangible souvenir can be referred to as scholarly souvenir; it is a memory of a significant experience that has enriched understanding of one's field (Salter and Meserve, 1991). Intangible souvenirs are a collection of experiences that help to shape the lives and perceptions of some tourists and can take a variety of forms that diversify the activities which deepen one understands of the reason that people have for travelling. Intangible souvenirs fall into two distinct types: A souvenir of a place, or a souvenir of an event. These types sometimes overlap, and once purchased, both aspects are considered intrinsic to the narrative of the object. An example of a souvenir of an event is an experience that one enjoys as one visits an event such as the celebration of Emancipation.

A souvenir of a place refers to an individual/a tourist visiting historical monuments to learn and understand what occurred in these monuments. The experience that tourists have as they visit historical monuments like castles, where human beings were given horrible treatment or a visit to a museum where evidence of human carnage is preserved, are all intangible souvenirs of places. Most tourists travel to Egypt, for example, to learn about ancient ways of burying their dead kings (the Pharaohs) and how their mummies are preserved for thousands of years. On the other hand, a souvenir of an event is basically the participation in various activities such as festivals, sporting events, Emancipation day, old students' reunion, Kidafest, etc. in order for the tourist to learn more about the way of life of other people as well as to identify with other cultures. 


\subsection{Tangible Souvenirs produced in Ghana}

According to the Ghana Tourist Board, Ghana offers many tangible souvenirs to tourists. Among the most important tangible souvenirs produced in Ghana for the international tourism market include beads, wood carvings, paintings, kente, smock or 'fugu', basketry, pottery, art works, hats, wood carvings, paintings of local beaches, festivals and rural life scenes. Most of these articles are available in specific places across tourism destinations in the country (www.ghanaweb.com, 2010), but are mostly available at the Accra Arts Centre, which was established in 1989 by the Government of Ghana under PNDC Law 238. Almost all the souvenirs at the centre are handmade, except the kente strips that are sewn together using machines after they have been handwoven on the loom.

Wood carvings, basketry and hats weaving as well as pottery all depend on raw materials such as wood, raffia and clay from the environment and usually from the wild. The sustainability of these raw materials especially raffia and canes have become a headache for the craftsmen. People have suggested the development of plantation projects where these materials could be planted to ensure their sustainability. There seems to be no problem with raw materials for the production of the kente and smock as their raw materials such as cotton are easily obtained on the market. For beads production, broken bottles and glass, which are the main raw materials, are never in short supply. Promotion of the finished products is sometimes a major hurdle to souvenir producers.

\subsection{Promotion of souvenirs for tourism development}

Promotion refers to communication between two sellers and potential buyers, to influence behavior. The main promotion job is to tell the target customers that the right product is available at the right place and the right time (William et al, 2001). It is the descriptive term for the mix of communicating activities, which tourism companies, or tourist boards carry out in order to influence those public on whom their sales depend. The important groups which need to be influenced are not simply the target market group of current and potential customers. There is the need also to influence trade contracts with retail agents and suppliers, as well as opinion formers such as journalists and travel writers. Even local, national and international groups may need to be influenced (Cooper et al., 2008).
Promotion is the communication process that uses information persuasively presented to achieve a positive customer response. It is divided into a number of functions called tactics embracing advertising, selling, publicity, brochures and sales aids, direct mail and sales promotion (Wearner, 2001). It has also been seen as the coordination of all seller initiated efforts to set up channels of information and persuasion to sell goods and services or promote an idea (Belch and Belch, 2001). Promotion could also mean activities that communicate the merits of the products and persuade target customers to buy them (Kotler and Armstrong, 1999).

Promotion is an essential element of the marketing mix. It contributes significantly to the total sales earned by any company. Lovelock (1984) describes it as a means where one provides the needed information and advice as well as persuading target consumers of the merits of a specific product, by companies producing goods and services. Lovelock (1984) adds that promotion helps businesses to offer their customers a package of benefits involving the delivery of not only the core benefit but also a variety of services related to the activities that they refer to as supplementary services to the purchase of specific goods. This supplementary services may include after sale services and specific period guarantees. The combination of the core products and supplementary services are often referred to as the augmented products, which are used to stress the uniqueness of a facility during advertising communication. This may also pertains to souvenirs bought on tour.

Souvenirs are very important in the promotion of tourism in Ghana because they are produced to depict various themes in the culture, vegetation, landscape and other unique resources that have something to do with the country as a whole. The promotion of tourism in Ghana can, therefore, be undertaken by the building of stories and ideas about these resources. Examples include the following: "Come to Ghana and walk on the only canopy walkway in Africa" or "Visit Buabeng-Fiema and shake hands with the monkeys".

Attention must be given to those who develop souvenirs to promote the uniqueness of the Ghanaian tourism products, since what the souvenirs convey to the tourists in the form of artifacts they buy, can help build a positive image of the country to attract more potential tourists. 


\section{Methodology}

This study was a survey of stakeholders in the souvenir trade at the Accra Arts Centre, involved respondents such as Management, some workers and exhibitors at the Centre as well as tourists visiting the Centre during the period of the research. In all, the total sample size of fifty-five was drawn (with the registration a non-response rate of $20 \%$ as 66 structured questionnaires were initially administered). The sample size was made up of twenty exhibitors and workers at the centre, five management staff and thirty tourists. The managers and exhibitors were selected purposively while the tourists were selected using accidental sampling technique. The tourists were made up of 18 males and 12 females, with their ages ranging between twenty two and sixty-five and were categorized into domestic $(52 \%)$ and international (48\%), with majority $(60 \%)$ of the former being West African nationals from neighbouring countries such as Nigeria, Cote d'Ivoire and Togo. This diversity in culture shows the importance of trans-border tourism in the West African sub-region.

\subsection{Instruments used for data collection}

In collecting information for the study, a structured questionnaire was administered to Management, exhibitors and the tourists. Personal interview schedule was also used to interview some of the respondents including Management and exhibitors/workers at the centre. The questionnaire had both open and close ended questions. Management included the human resource manager and staff of some functional departments at the Arts Centre such as the Finance Officer. On the part of exhibitors, the questionnaires were administered to those who showed interest in the study.

\subsection{Limitations of the study}

As with most research works, some limitations are associated with this study. It was initially stated that souvenirs are produced all over destinations scattered across the country, however, the study was limited to a survey conducted at one particular souvenir sales spot in Accra; the Arts Centre. This may limit the extent of applicability of the findings. Nevertheless, almost all examples of souvenirs produced in Ghana are available at the Arts Centre. This lends credibility to the use of the centre to epitomize the types of souvenirs available for tourists visiting the country. Secondly, the research was conducted in only a week which limits the number of tourists involved. The time duration was not the best for such a study. However, these limitations did not affect the results of the study.

\section{Results and discussion}

The study showed that majority of the tourists involved (80\%), intimated that they purchased souvenirs as evidence to show their relatives, friends and colleagues back home that indeed they have visited Ghana. They also purchased the souvenirs to satisfy their curiosity regarding the information they have acquired in their various countries about Ghana especially regarding the country's hospitable people, wildlife, forts, castles and festivals. A higher number of the tourists were satisfied with the souvenirs they purchased and attached much value to them. Few of the tourists purchased souvenirs based on what the exhibitors told them about those souvenirs.

\subsection{Reasons for souvenir purchase at the Accra Arts Centre by tourists}

It was decided that reasons for tourists deciding to buy souvenirs from the centre would be unearthed. The results obtained are presented in Table 1. Out of the thirty tourists, ten $(33 \%)$ indicated that they decided to buy from the Centre, because the place is quite accessible to tourists visiting Ghana. Only five $(17 \%)$ of the tourists indicated that they decided to pick souvenirs from the Centre because the exhibitors can narrate legends associated with the souvenirs.

Table 1

Deciding to visit the Accra Arts Centre to purchase a souvenir

\begin{tabular}{lll}
\hline Responses & Frequency & Percentage \\
\hline The centre is accessible & 10 & 33 \\
The Exhibitors are affable & 7 & 23 \\
The exhibitors know stories about the souvenirs & 5 & 17 \\
The centre is neat and lively & 8 & 27 \\
\hline Total & $\mathbf{3 0}$ & $\mathbf{1 0 0}$ \\
\hline
\end{tabular}

Source: Author's Fieldwork, May 2010

The statistics shown in Table 1 indicate that tourists visiting the country and deciding to buy from the Centre had good remarks about the Centre. 
Their general remarks about the Centre were encouraging. However, this does not mean there was no room for improvement as only 7 tourists $(23 \%)$ said the exhibitors are affable. It was also decided to find from the tourists their reasons for purchasing the types of souvenirs being exhibited at the Centre. The results are presented in Fig. 1, from which it can be noted that only 5 out of the 30 tourists sampled (17\%) were of the view that they purchased their souvenirs at the Art Centre because they were affordable, while 12 of the tourists $(40 \%)$ were of the opinion that the souvenirs looked authentic. It is notable that only 3 tourists $(10 \%)$ said that some of the souvenirs had a nice finish. This may mean that these tourists thought that there was the need to improve on the finishing of some of the products, especially the hats and leather products. This confirms the statement of Abendroth et al (2011) that the finishing of souvenirs attracts buyers.

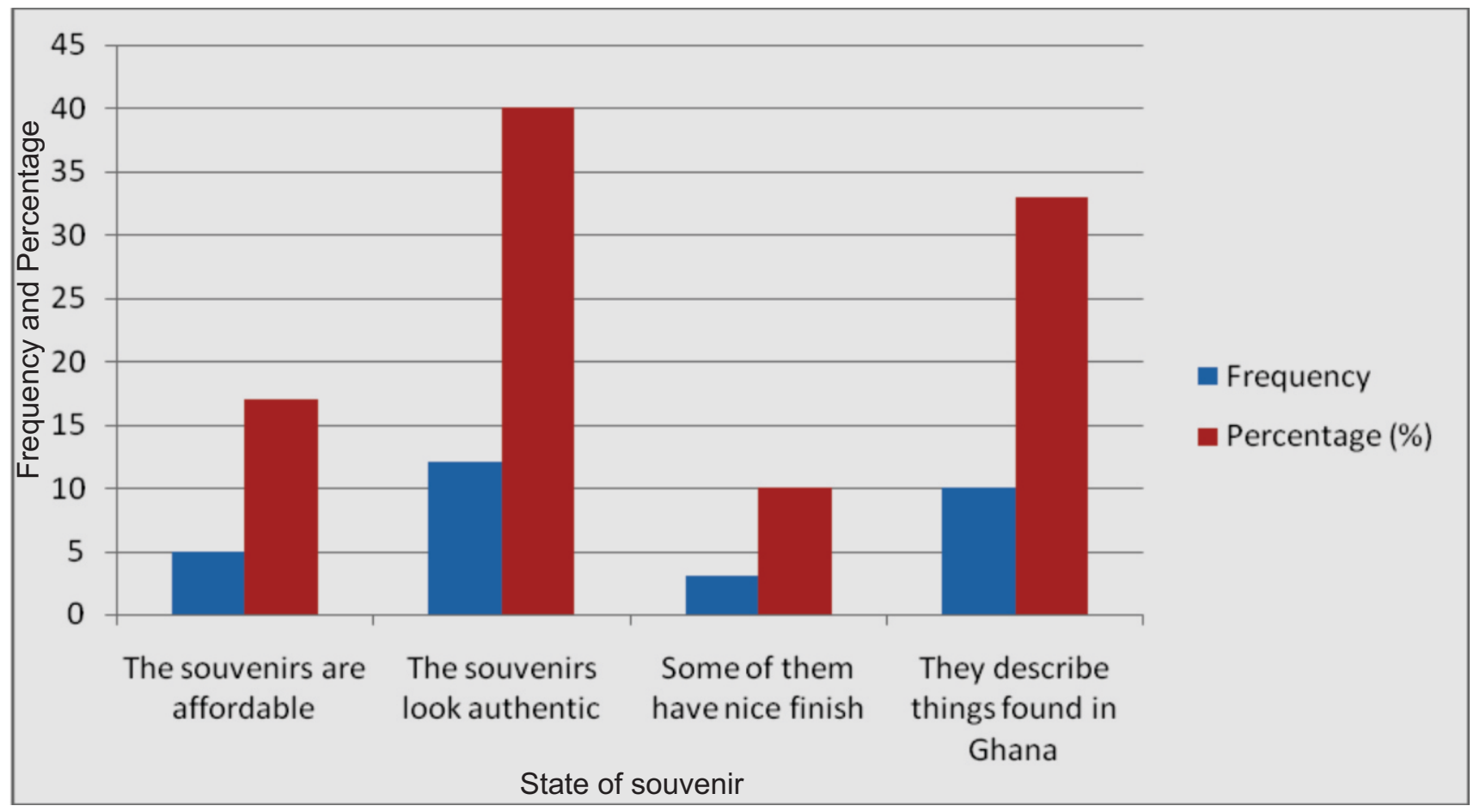

Source: Author's Fieldwork, May 2010

Fig. 1: Reasons for purchasing souvenirs at the Arts Centre

Another important issue was for the researcher to examine the tourists' sources of information about the Centre. The results obtained are illustrated in Table 2. Eleven out of the thirty tourists (37\%), who were mostly repeat visitors to the country, indicated that they learnt about the Centre from the Internet, while 10 of them $(33 \%)$ showed that they learnt about the Centre from magazines or travel brochures. This attests to the importance of the internet in advertisement regarding tourism products in the country.

Table 2

How tourists got information about the Centre

\begin{tabular}{lll}
\hline Sources & Frequency & Percentage \\
\hline From the Internet & 11 & 37 \\
From magazines and brochures & 10 & 33 \\
From friends and relatives & 6 & 20 \\
From television documentaries & 3 & 10 \\
\hline Total & $\mathbf{3 0}$ & $\mathbf{1 0 0}$ \\
\hline
\end{tabular}




\subsection{Responses of exhibitors operating at the Accra Arts Centre}

It became necessary for the researcher to know why the exhibitors chose the Accra Arts Centre to sell their products. Table 3 shows the results. It can be clearly seen that 6 exhibitors decided to sell at the art centre because it was well noted to tourists whereas the remaining 4 exhibitors consisting of 2 each said, they wanted to be recognized and also the Centre's location was a factor. The study discovered that there is a high purchase of souvenir during peak season and low purchase during lean seasons. Majority of the exhibitors suggested that the Management should assist them to market their product in a form of media advertisement as well as trade fairs.

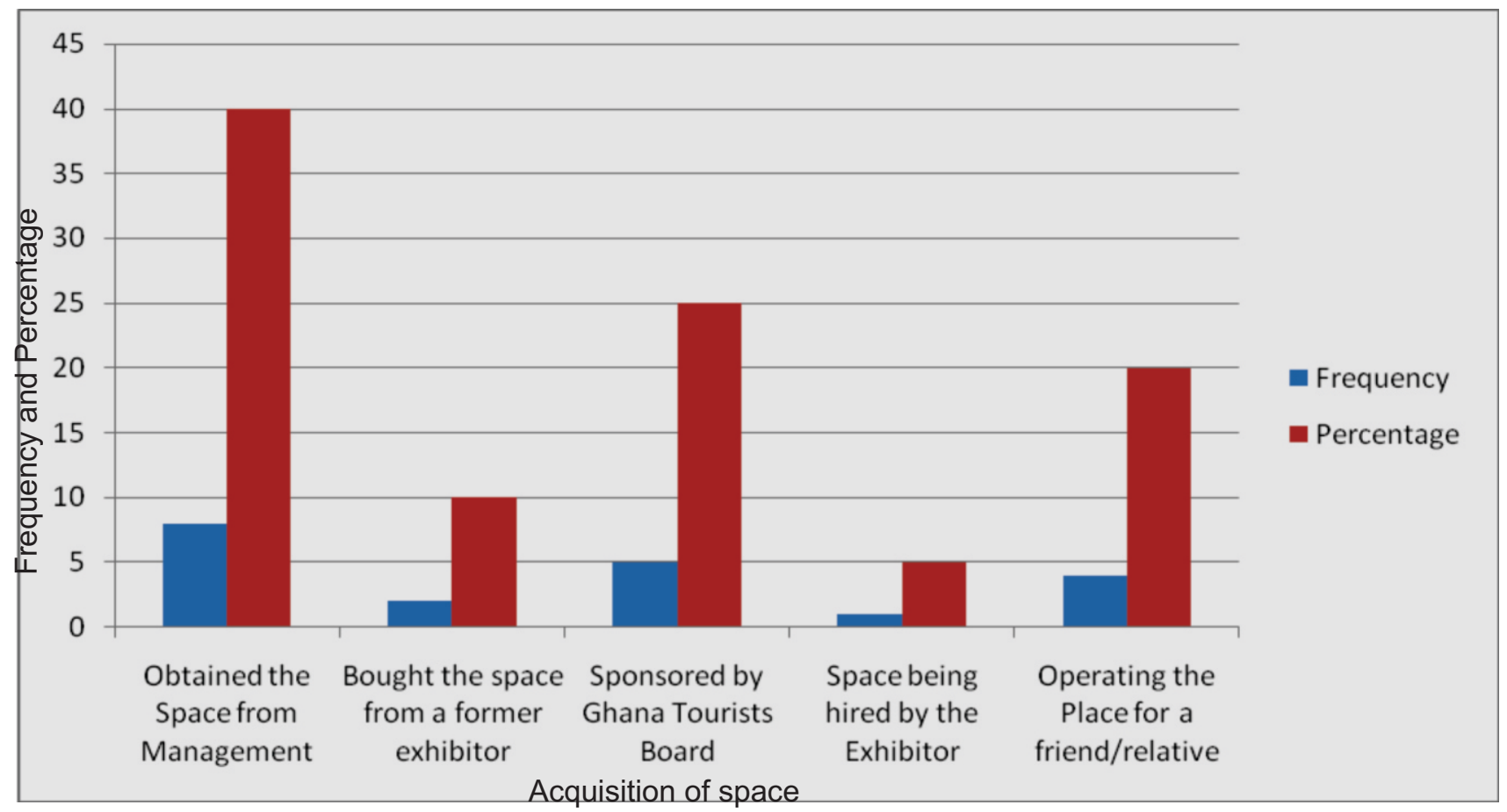

Source: Author's Fieldwork, May 2010

Fig. 2: How exhibitors got spaces at the Arts Centre

Table 3

Why exhibitors chose to sell souvenirs at the Arts Centre

\begin{tabular}{llc}
\hline Responses & \multicolumn{2}{l}{ Frequency Percentage } \\
\hline Well patronized by tourists & 6 & 30 \\
Obtains satisfaction & 1 & 5 \\
Makes a lot of profit & 2 & 10 \\
Enjoys talking about Ghana's culture to foreigners & 7 & 35 \\
Makes a lot of friends & 4 & 20 \\
\hline Total & $\mathbf{2 0}$ & $\mathbf{1 0 0}$ \\
\hline
\end{tabular}

Source: Author's Fieldwork, May 2010 
The study revealed that most of the exhibitors at the Centre acquired their production knowledge and skills from their parents. The study also established that the exhibitors did not have all the resources to meet the needs of tourists to the maximum resulting in the inability of the management to stop operations of non-recognized sellers of souvenirs at other places in Accra. Finally, the exhibitors came out with major challenges they faced such as the payment of high taxes to the Management and the Accra Metropolitan Assembly (AMA), even during lean seasons.

\subsection{Responses from management of the Centre}

As seasonality is a problem with tourism development, the researcher decided to find out what efforts Management usually put in place during lean seasons, when souvenir purchases at the Centre is at its lowest ebb. The responses are presented in Table 4, from where it can be deduced that much concerted effort is put in place by the Management during lean season to encourage souvenir sales. The forceful encouragement of advertising recorded the highest frequency of 4 and this was followed by the effort of organizing the tourists which recorded the frequency of 3 . However, the effort of the researcher to the Ghana Tourist Board to recommend the Centre to visiting tourists recorded the lowest frequency of one respondent.

Table 4

Effort of management during the lean season.

\begin{tabular}{lll}
\hline Responses & Frequency & Percentage \\
\hline Forceful encouragement of advertising & 4 & 40 \\
Organizing tourists visits & 3 & 30 \\
Use of price discrimination & 2 & 20 \\
Appealing to Ghana Tourist Board & 1 & 10 \\
\hline Total & $\mathbf{1 0}$ & $\mathbf{1 0 0}$ \\
\hline
\end{tabular}

Source: Author's Fieldwork, May 2010

\subsection{Promotional tools preferred by exhibitors at the Arts Centre}

Many tools exist for the promotion and sale of souvenirs. Table 5 was put together for the researcher to ascertain what promotional tool exhibitors preferred that management should use to raise souvenir marketing and purchasing at the Arts Centre. It can be clearly seen from the table that the highest promotional tool that exhibitors wanted management to introduce at the centre was electronic media advertisement which represented 60 percent of responses. Interestingly, bill boards and international brochures recorded $20 \%$ while the promotional tools with the use of trade shows and conferences recorded the lowest percentages of 10 each.

Table 5

Promotional tool that Management should introduce in the Lean Season

\begin{tabular}{lll}
\hline Responses & Frequency & Percentage \\
\hline Advertisement in the Electronic media & 6 & 60 \\
Trade shows & 1 & 10 \\
Bill boards and international brochures & 2 & 20 \\
Conferences & 1 & 10 \\
\hline$\quad$ Total & $\mathbf{1 0}$ & $\mathbf{1 0 0}$ \\
\hline
\end{tabular}

Source: Author's Fieldwork, May 2010

\subsection{Management's Responses on the Contributions of the Souvenir Trade}

As part of the study, the Management of the Accra Arts Centre was interviewed to assess their views concerning some products. The responses of the Management to the questions were analysed. There are five departments at the centre to facilitate division of labour, exhibit professionalism and allow easy accessibility of tourists to the management. Regarding the relationship between the exhibitors and tourists and also patronage of the souvenir trade, the management's response was that there was cordial relationship between tourists and exhibitors and also patronage of the Centre by buyers was encouraging.

Regarding measures that the management would like to introduce in terms of data processing on souvenir promotion, packaging and sales, their response was that there should be organization of regular workshops and seminars for exhibitors and also advertising coverage of souvenir production by the media and on the Internet. On the contribution of the Ghana Tourist Board (GTB) in the promotion of souvenirs for tourism development in Ghana, the management's response was that there was no direct contribution by the GTB; however they help in ensuring good sanitary conditions at the area. It was also learnt that the exhibitors were issued identification cards to differentiate them from others and to show that they belong to a trade union at the Centre.

It was noted that the management at the Centre is divided into five sections. Each section plays specific roles such as recruitment, exhibition development, 
tourist welfare, selection, planning and sanitation. It was noted that the division of the management has facilitated specialization, exhibited professionalism, and encourage easy accessibility of tourists and exhibitors. It was also discovered that the souvenir trade is helping in promoting tourism to sustain the nation's culture.

It was also known that although the Ghana Tourist Board (GTB) has no direct contribution to souvenir promotion at the Centre, they bring tourists to the Centre to buy the souvenirs when they visit the country. In addition, they keep an eye on sanitation conditions at the Centre. Finally, the study came out with the fact that exhibitors at the Centre have no reason to complain of competition with local sellers of souvenirs, as the latter are an identified body with a union which is recognized by the Ministry of Tourism.

\section{Recommendations}

Souvenir production is an old industry blended with modern civilization and as such is considered to be an important prerequisite for the development of tourism. In addition to the fact that they are needed by citizens and non citizens alike, souvenirs carry with them the essence of a destinations' culture and identity. Souvenirs seem to be a vital promotional tool for tourism in any country. Therefore the following recommendations made for the GTB to ensure that souvenirs enhance tourism promotion in the country. Based on the fact that souvenir production is a nationwide industry, there is the need for the GTB to educate manufactures of souvenir products, who use wood on mass tree planting to replace those they cut down to ensure sustainability of their business. The tree planting education must also be extended to rural communities where wood is used for energy, building of houses and in the making of canoes for fishing.

It was discovered that souvenir packaging was not of a major concern to the manufacturers in the country. Although they take into consideration souvenirs durability, quality and packaging to differentiate their products from other souvenirs manufactured from other countries. It is, therefore, recommended that workshops and seminars should be organised for souvenir manufacturers and exhibitors to focus on their packaging. For example, national logos should be attached to souvenirs, and the souvenirs should be given brighter colours to catch the attention of tourists. he workshop should also factor in it technology in souvenir production to make souvenirs produced in Ghana unique.

It was also realized from the study that the Management gave no support to souvenir advertisement in the country. Exhibitors advertise their products based on their purchasing power. It is, therefore, recommended that the Management of the Arts Centre should give support to exhibitors in terms of advertisement to promote the sales of souvenirs in the country. The Management can create an interactive website for exhibitors that will showcase their products and have the ability to sell the products on-line to customers.

Based on the suggestions of tourist, the National Tourism Authority should use souvenirs to brand the nation and national symbols should be represented on souvenirs made in the country (Balakrishnan et al, 2011). It was also discovered that majority of exhibitors had low level of education, which prevented them from communicating directly with tourists. It is, therefore, recommended that, during workshops and seminars for exhibitors, they should be enlightened on the importance of education and bilingualism which must include the English language.

In ensuring that tourists are given authentic experiences, destination managers must avoid staging events and over innovating historic attractions (Cooper et al, 2008) as some tourists are more concerned with entertainment and excitement than authentic issues.

Finally, throughout the research, the difficulty that the Management faced in convincing the government to come to their aid in terms of souvenir marketing was noted. As the Arts Centre and other souvenir centres in the country had no direct contact with the Ghana Tourist Board (GTB), much difficulty exists in the organization of international fairs for exhibitors.

It will, therefore, be laudable for the Ministries of Tourism and that of Chieftaincy and Culture to come into collaboration with the GTB to support souvenir promotion in the country and on the international market to promote Ghana as an important tourism destination in West Africa.

\section{Conclusion}

In conclusion, the study revealed that international tourists viewed souvenirs that are made in the image of animals they saw in some of the 
national parks in Ghana, as highly authentic. The female tourists, however, were not delighted with feminine carvings as mere their male counterparts, who purchased some of these souvenirs. What was unique about the wood carvings that thrilled the tourists most was their finishing, which they intimated compared favourably with those they had seen outside Africa?

However, some of the tourists complained of foul smell emanating from some of the souvenirs made from leather. This shows that the preparation of materials for such souvenirs needs improvement so as to make them readily acceptable by international tourists who buy them to take home to show their friends and relatives that they have been to the West African state of Ghana. Finally, it was further suggested that it would be necessary for the GTB to undertake an examination of souvenirs produced in the hinterland of Ghana, especially in the three northern Regions of the country where the promotion of a variety of souvenirs produced, could help in the overall tourism development in the country.

\section{References}

Abendroth, L. J., (2011). The Souvenir purchase decision: Effects of Online Availability, International Journal of Culture, Tourism and Hospitality Research Vol.5 No. 2 pp.105-121.

Appadurai, A., (1986). Introduction to Commodities and the Politics of Value. In the Social Life of Things; Commodities in Cultural Perspective, A. Appadurai, (ed.) Cambridge University Press.

Balakrishnan, M. S.,Nekhili, R. and Lewis, C. (2011), Destination Brand Components, International Journal of Culture, Tourism and Hospitality Research Vol.5 No.1 pp.85 102.

Belch G. and Belch, M. A., (2001). Advertising and Promotion: An Integrated Marketing Communications Perspective, McGraw-Hill-Boston.

Boynton, L, (1986). The Effect of Tourism on Amish Quilting Design, Annals of Tourism Research Vol.13 pp.451-465.

Briggs, C. L., (1980), The Wood Carvers of Cordova, New Mexico. Knoxville: The University of Tennessee Press.
Cooper, C., Fletcher, J., Gilbert, D. and Wanhill, S. (2008). Tourism Principles and Practice. London: Longman.

Franklin, A. and Crang, M., (2001). The Trouble with Tourism and Travel Theory, Tourist Studies Vol.1, No.1, pp. 5-22.

Gordon, B., (1986). The Souvenir: Messenger of the Extraordinary, Journal of Popular Culture, vol. 20,No. 3, pp. 135-146.

Hitchcock, M., (2000). Ethnicity and Tourism Entrepreneurship in Java and Bali, Current Issues in Tourism, Vol.3, pp. 204-225.

Kotler, P. and Armstrong, G., (1999). Principles of Marketing, Upper Saddle River, New Jersey: Prentice Hall.

Lane, R. and Waitt, G., (2007). 'Inalienable Places: Self-drive Tourists in Northwest Australia', Annals of Tourism Research Vol.34, No.1, pp. 105-121.

Lovelock, C. H., (1984). Services Marketing, Upper Saddle River, Prentice Hall, NJ.

Olsen, K., (2002). Authenticity as a Concept in Tourism Research; The Social Organization of the Experience of Authenticity, Tourist Studies, No. 2, pp. 159-182.

William D., Perreault, J. and McCarthy, E. (2001). Essentials of Marketing (7th edn.), McGraw Hill, New York.

Salter, C.L., and Meserve P. (1991): Life Lists and the Education of a Geographer, Professional Geographer, No. 43, pp. 520-525.

Shenhav-Keller, S., (1993). The Israeli Souvenir: Its Text and Context, Annals of Tourism Research, No.20, pp. 182-189

Wearner, N., (2001). Hospitality Marketing, Melbourne Hospitality Press Limited.

www.ghanaweb.com, 09/05/2010, Availability of Souvenirs at Destinations across Ghana, Accra: Ghana Tourist Board. 